Vol. 01, No. 1, Mei, 2021

http://journal.um-surabaya.ac.id/index.php/sustainable/index

\title{
ANALISIS AKUNTANSI BIAYA PRODUKSI MESIN DENGAN METODE FULL COSTING DALAM MENETAPKAN HARGA POKOK PRODUKSI MESIN PADA PT. CAHAYA AGRO TEKNIK SURABAYA
}

\author{
Sriyati \\ Universitas Muhammadiyah Surabaya \\ sriymulyani98@gmail.com
}

\begin{abstract}
The purpose of this study was to determine the extent to which the calculation of the cost of production using the full costing method the determine the cost of production at PT.Cahaya Agro Teknik Surabaya. Researchers used data sources consisting of primary data consisting of primary data and secondary data. The secondary theory is the theory obtained from the existing literature theory data, while the primary data is obtained from the company PT. Cahaya Agro Teknik Surabaya. In this study, the researcher used descriptive method with a qualitative method approach. Descriptive research method is research on problems that occur in the company and qualitative method is a research procedure that produces descriptive data consisting of written or oral forms of people and behaviors that researchers observe. The tools used for research use the full costing method. The researchers use the full costing method because the full costing method is one method of determining the costs of production that takes into account all elements of production costs into the costs of production. The results of the research that researchers have done are in calculating the cost of production using the full costing method to produce a higher value than the method applied by PT. Cahaya Agro Teknik Surabaya. This is because PT. Cahaya Agro Teknik Surabaya does not fully calculate the costs, both variable and fixed. The results of the analysis in calculating the cost of production using the full costing method for plastic 50 miliing mechines amounting to Rp.170.723.300, plastic 100 milling machines of Rp.300.976.260, plastic 200 milling mechines of Rp .509.424.300 and coconut milk machine of Rp. 169.424.300
\end{abstract}

Keywords: Full Costing Method, Cost of Production, Analysis

\begin{abstract}
ABSTRAK
Tujuan penelitian ini adalah untuk mengetahui sejauh mana perhitungan harga pokok produksi dengan menggunakan Metode full costing untuk menetapkan harga pokok produksi pada PT. Cahaya Agro Teknik Surabaya. Peneliti menggunakan sumber data yang terdiri dari data primer dan data sekunder. Teori sekunder adalah teori yang diperoleh dari data kepustakaan yang ada, sedangkan data primer diperoleh dari perusahaan PT. Cahaya Agro Teknik Surabaya.Dalam penelitian ini peneliti menggunakan Metode diskriptif dengan pendekatan Metode kualitatif. Metode penelitian kualitatif deskriptif adalah penelitian terhadap masalah yang terjadi diperusahaan dan Metode kualitatif adalah prosedur penelitian yang menghasilkan data secara deskriptif yang terdiri dari kata bentuk tertulis atau lisan dari orangorang yang peneliti amati. Alat yang digunakan untuk penelitian menggunakan Metode Full Costing karena Metode penentuan harga pokok produksi yang memperhitungkan semua unsur biaya produksi ke Dalam harga pokok produksi.Hasil peneliti yang telah peneliti lakukan adalah Dalam perhitungan harga pokok produksi dengan menggunakan Metode full costing menghasilkan nilai yang lebih tinggi dibandingkan dengan Metode yang diterapkan oleh PT.Cahaya Agro Teknik Surabaya. Hal ini dikarenakan PT.Cahaya Agro Teknik Surabaya tidak sepenuhnya melakukan perhitungan harga pokok produksi baik yang bersifat variable maupun tetap. Hasil analisis Dalam perhitungan harga pokok produksi menggunakan Metode full costing untuk mesin giling plastic 50 sebesar Rp 170.723.300, Mesin
\end{abstract}




\section{Jurnal Sustainable}

Vol. 01, No. 1, Mei, 2021

http://journal.um-surabaya.ac.id/index.php/sustainable/index

Giling Plastik 100 sebesar Rp 300.976.300, Mesin Giling Plastik 200 Sebesar Rp 509.424.300 dan mesin peras santan sebesar Rp 169.424.300.

Kata Kunci: Metode Full Costing, Harga Pokok Produksi, Analisis

Submitted: Maret 2021

Revised: April 2021

Accepted: Mei 2021

Correspondence to : sriymulyani98@gmail.com

\section{PENDAHULUAN}

Seiring dengan perkembangan zaman saat ini, khususnya dalam dunia bisnis maka ada beberapa unsur yang harus diperhatikan dalam merencanakan bisnis. Adapun unsur yang harus diperhatikan dalam bisnis antara lain adalah planning, organizing, and controlling. Perusahaan sebelum melakukan bisnis hal yang perlu di perhatikan adalah perencanaan karena sangat mempengaruhi kelangsungan sebuah bisnis yang dijalankan oleh manajemen mempengaruhi dalam Menyusun rencana kedepannya. (Mulyadi 2012:10).

Akuntansi biaya adalah seluruh biaya yang digunakan dalam memproduksi bahan baku menjadi produk yang bisa dinikmati oleh konsumen, yang termasuk biaya produksi adalah biaya bahan baku, biaya tenaga kerja langsung dan biaya overhead pabrik. Selain biaya yang termasuk biaya variable dan biaya tetap ada biaya nonproduksi contohnya biaya pemasaran, biayaadministrasi dan umum. Biaya non produksi digunakan untuk menghitung cost produksi, yang terdiri dari cost jadi dan cost produk yang pada akhir priode akuntansi masih dalan proses. (Mulyadi 2012:16).

Perhitungan harga pokok produksi adalah menghitung seluruh biaya produksi yang terdiri dari biaya bahan baku, biaya tenaga kerja langsung, dan biaya overhead pabrik. (Bustami dan Nurlela 2013:49). Biaya adalah sumber informasi yang sangat penting dalam analisis strategic perusahaan. Dengan adanya menganalisis biaya yang dikeluarkan perusahaan nantinya akan menggambarkan kinerja perusahaan tersebut. (Rusdiyanto 2016).

Analisis akuntansi biaya harus dilakukan dengan benar dan terperinci baik dari penggolongan biaya dan pengklasifikasian sehingga nantinya akan bermanfaat dalam harga jual produk dan mendapatkan laba semaksimal mungkin. Kelalaian dalam memperhitungkan biaya produksi akan mempengaruhi suatu laba yang dihasilkan oleh perusahaan. 


\section{Jurnal Sustainable}

Vol. 01, No. 1, Mei, 2021

http://journal.um-surabaya.ac.id/index.php/sustainable/index

Perusahaan dalam memperhitungkan harga pokok produksi masih menggunakan metode yang sangat sederhana dan belum merinci seluruh biaya yang dikeluarkan Dan dalam proses produksi perusahaan melakukan perhitungan harga pokok produksi mesin perusahaan hanya membebankan biaya bahan baku, biaya tenaga kerja, biaya overhead pabrik dan biaya penyusutan. Biaya overhead yang dibebabankan hanya biaya listrik, dan biaya penyusutan alat produksi. Hal ini dalam penggolongan biaya harus secara teliti karena sangat mempengaruhi laba perusahaan yang didapatkan.

Untuk mengatasi kelalaian dalam perhitungan harga pokok produksi dan menghasilkan harga jual yang tepat maka diperlukan metode yang tepat. Metode yang tepat untuk perhitungan harga pokok produksi adalah metode full costing. Dengan menggunakan metode ini diharapkan akan membantu perusahaan khususnya pada pihak manajemen perusahaan dalam menetapkan harga pokok produksi dan sebagai pengambilan keputusan anggaran.

\section{TINJAUAN TEORITIS}

\section{Akuntansi}

Menurut Rudianto (2012:4) bahwa akuntansi adalah sebuah aktivitas dari teknik mengumpulkan, menganalisis, menyajikan dalam bentuk angka sehingga bisa mengklasifikasikan, mencatat, meringkas dan melaporkan aktivitas suatu badan untuk mendapatkan sebuah informasi baik keuangan maupun suatu pengambilan keputusan.

Statement of Financial Accounting Concept (SFAC) Nomor 1 (Bardidwan 2015:2) menjelaskan bahwa laporan keuangan harus menyajikan informasi yang bisa digunakan selain itu juga tujuan laporan keuangan dapat membantu investor dan kreditur yang ada dan yang potensial untuk menaksir jumlah, waktu.

\section{Akuntansi Biaya}

Menurut Mulyadi (2015:8) akuntansi biaya adalah pengorbanan sumber ekonomi yang diukur baik itu yang sedang terjadi, maupun yang akan terjadi untuk tujuan aktiva dan tujuan tertentu.

\section{Biaya Produksi}

Menurut Putra (2018:116) biaya produksi adalah seluruh biaya yang terkait akibat adanya proses kelangsungan produksi. Tujuan produksi adalah sebuah kegiatan mengolah 


\section{Jurnal Sustainable}

Vol. 01, No. 1, Mei, 2021

http://journal.um-surabaya.ac.id/index.php/sustainable/index

bahan baku menjadi barang jadi sehingga nantinya siap dijual ke konsumen. Hal yang dibutuhkan untuk dapat menghasilkan sebuah produk adalah bahan baku langsung, tenaga kerja langsung, tenaga kerja tidak langsung, bahan penolong, dan fasilitas pendukung.

a. Biaya Bahan Baku

Menurut Mulyadi (2010:275) bahwa biaya bahan baku adalah bahan yang digunakan paling pokok dalam memproduksi barang menjadi barang jadi. Setiap perusahaan Dalam pengklasifikasian biaya bahan baku berbeda-beda, pada perusahaan industri biaya bahan baku yang diperoleh dapat melakukan pembelian local, impor dan pengolahan sendiri.

b. Biaya Tenaga Kerja

Menurut Mursyidi (2010:213) bahwa biaya tenaga kerja terbagi menjadi dua yaitu biaya tenaga kerja langsung dan tenaga kerja tidak langsung. Biaya tenaga kerja langsung adalah biaya yang dikeluarkan perusahaan untuk kepentingan langsung dalam proses produksi. Contoh dari biaya tenaga kerja langsung adalah biaya pekerja bagian produksi pabrik. Dan biaya tenaga kerja tidak langsung adalah biaya yang tidak langsung berhubungan dengan proses produksi, contohnya gaji manajer, dan gaji administrasi.

c. Biaya Overhead Pabrik

Menurut Mulyadi (2012:194) menjelaskan bahwa biaya yang bukan termasuk biaya bahan baku dan biaya tenaga kerja langsung. Biaya overhead pabrik dapat diklasifikasikan beberapa klasifikasi yang terdiri dari biaya bahan penolong, biaya reparasi dan pemeliharaaan, biaya tenaga kerja tidak langsung, biaya yang timbul akibat penilaian aktiva tetap, dan biaya yang timbul sebagai akibat berlalunya waktu.

\section{Teknik pengumpulan biaya produksi}

Menurut Mulyadi (2015:17) dalam pengumpulan biaya produksi terdapat beberapa Metode yang terdiri dari metode harga pokok proses dan Metode harga pokok pesanan.

a. Metode harga pokok proses

Process costing method adalah biaya yang terbentuk kumpulan biaya produksi 


\section{Jurnal Sustainable}

Vol. 01, No. 1, Mei, 2021

http://journal.um-surabaya.ac.id/index.php/sustainable/index

berdasarkan pada produksi massa. Dalam metode ini dilakukan secara proses masa untuk memenuhi persediaan gudang.

b. Metode harga pokok pesanan

Job order costing method adalah metode pengumpulan harga pokok produksi. Dengan metode ini perusahaan biasanya hanya memproduksi barang sesuai pesanan costumer. Biaya produksi dikumpulkan untuk setiap biaya secara terpisah.

\section{Harga Pokok Produksi}

Menurut Mulyadi (2015:17) bahwa metode penentuan harga pokok produksi adalah menghitung unsur-unsur biaya kedalam biaya produksi. Metode harga pokok produksi terbagi menjadi 2 metode perhitungan adalah sebagai berikut:

a. Metode Full Costing

Metode full costing adalah menghitung biaya yang dipakai sebagai dasar harga jual yang terdiri dari biaya bahan baku, biaya tenaga kerja langsung, dan biaya overhead pabrik baik yang bersifat variable atau biaya tetap. Berikut perhitungan dengan menggunakan Metode full costing :

Biaya bahan baku $x x x$

Biaya Tenaga Kerja Langsung $x x x$

Biaya Overhead Pabrik :

Biaya Overhead Tetap $\quad$ xxx

Biaya Overhead Variabel $\quad \underline{x x} \quad+$

$x x x$

Menurut Widilestariningtyas et al (2012:16) dalam metode perhitungan laba rugi menurut full costing adalah sebagai berikut :

Penjualan $X X X$

Harga Pokok Penjualan $(\underline{x x})$

Laba kotor atas penjualan $x x x$

Biaya Komersial:

Pemasaran

Administrasi dan umum

Laba bersih 


\section{Jurnal Sustainable}

Vol. 01, No. 1, Mei, 2021

http://journal.um-surabaya.ac.id/index.php/sustainable/index

b. Metode harga pokok variable costing

Metode variable costing adalah Metode penentuan biaya produksi yang hanya memprhitungkan biaya produksi yang bersifat variable yang terdiri dari biaya bahan baku, biaya tenaga kerja langsung dan biaya overhead pabrik variable. Berikut perhitungan Metode variable costing adalah sebagai berikut:

Biaya bahan baku

Biaya tenaga kerja langsung

Biaya overhead variable

Biaya Produksi Variabel $x x x$

$\mathrm{xxx}$

$\underline{\mathrm{xxx} \quad+}$

Menurut Widiestraningtiyas (2012:67) penetuan harga pokok produksi pada umumnya manajemen dalam rangka pengambilan keputusan Dalam Menyusun laba rugi pada penyajian biaya sesuai dengan prilaku biaya menurut variable costing adalah sebagai berikut :

Penjualan $\mathrm{XXX}$

Harga pokok penjualan variable $(\mathrm{xxx})$

Batas kontribusi bersih $X X X$

Biaya komersial variable :

Pemasaran variable $\mathrm{xxx}$

Administrasi dan umum variable $x x x$

Batas kontribusi bersih $(\underline{x x x})$

Biaya tetap :

Overhead pabrik $x x x$

Pemasaran tetap $x x x$

Administrasi dan umum tetap $x x x$

Laba bersih

(xxx)

$x x x$ 


\section{Jurnal Sustainable}

Vol. 01, No. 1, Mei, 2021

http://journal.um-surabaya.ac.id/index.php/sustainable/index

\section{Kerangka Konseptual}

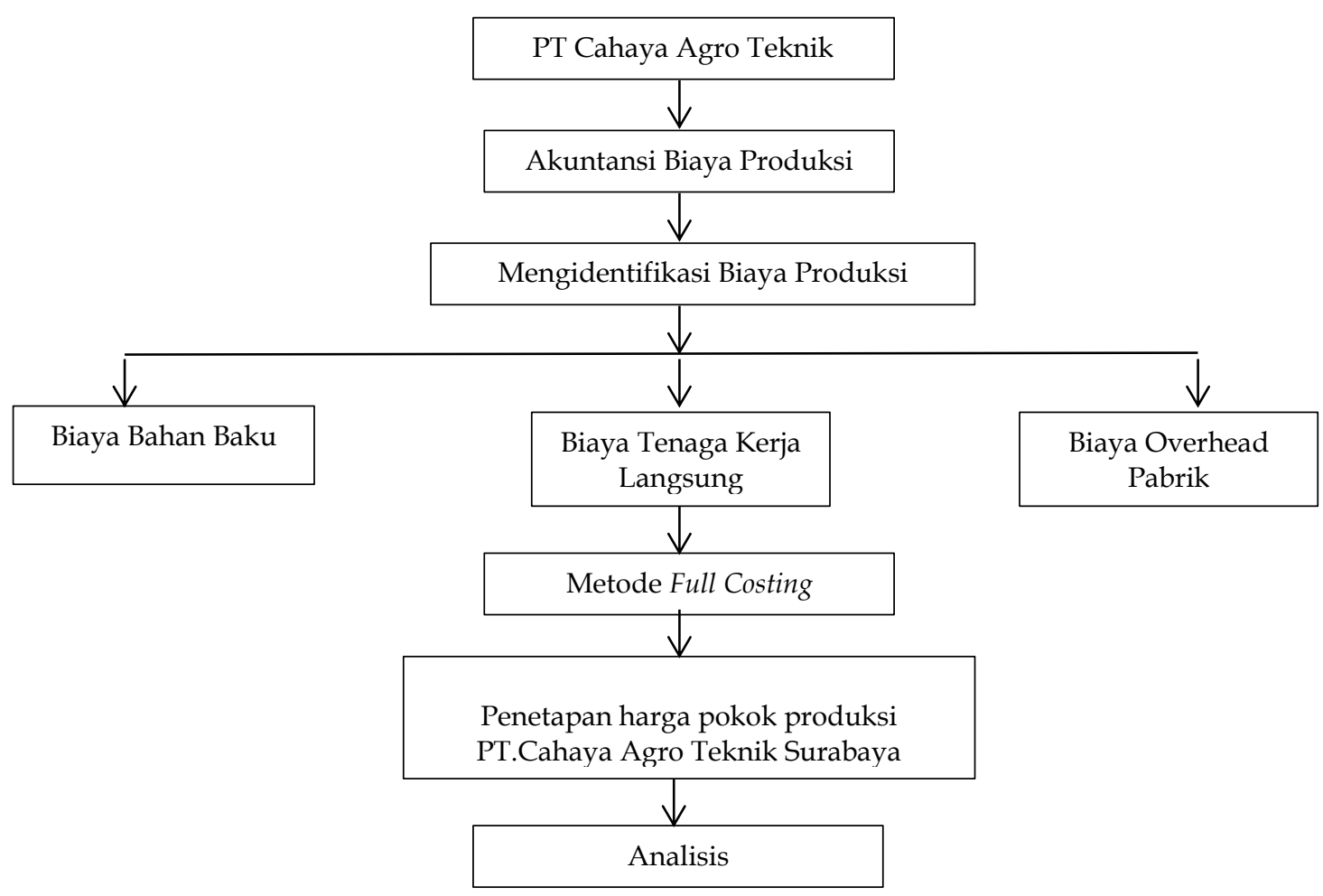

Gambar 1. Kerangka Konseptual

\section{METODE PENELITIAN}

\section{Jenis Penelitian}

Jenis penelitian yang penulis gunakan adalah penelitian kualitatif diskriptif, penelitian kualitatif diskriptif adalah penelitian yang memproleh informasi terkait harga pokok produksi yang tepat, sehingga penulis bisa menganalisis harga pokok yang diterapkan oleh perusahaan dibandingkan dengan metode full costing.

\section{Obyek Penelitian}

Obyek yang akan diteliti yakni perusahaan PT.Cahaya Agro Teknik Surabaya.

\section{Pengumpulan Data}

Teknik pengumpulan data menggunakan wawancara dan dokumentasi.

\section{Tahapan Analisis}




\section{Jurnal Sustainable}

Vol. 01, No. 1, Mei, 2021

http://journal.um-surabaya.ac.id/index.php/sustainable/index

Tahapan analisis dengan mengidentifikasi data biaya produksi, seperti biaya bahan baku, biaya tenaga kerja, dan biaya overhead pabrik, mengevaluasi komponen biaya berdasarkan pengklasifikaisan seperti biaya bahan baku yang dibutuhkan selama produksi, biaya tenaga kerja langsung dan biaya overhead pabrik yang bersifat variable maupun tetap.

Selanjutnya dilakukan penyusunan dan perhitungan biaya produksi dengan menggunakan metode full costing. Dalam menghitung harga pokok produksi metode full costing perlu melakukan data produksi dalam periode tertentu, mendiskripsikan dan melakukan perhitungan harga pokok produksi dan menghitung harga pokok produksi satuan setiap elemen. Dan peneliti juga memberikan kesimpulan dan saran kepada perusahaan metode yang paling efektif dalam pengkasifikasian biaya.

\section{HASIL PENELITIAN DAN PEMBAHASAN}

1. Mengidentifikasi data biaya produksi, biaya bahan baku, biaya tenaga kerja langsung dan biaya overhead pabrik

a. Biaya bahan baku

Perusahaan PT. Cahaya Agro Teknik Surabaya memproduksi lima unit, mesin yang terdiri dari type mesin giling 50, type mesin plastic 100, type mesin giling 200, dan mesin peras santan. Berikut adalah daftar biaya bahan baku yang dibutuhkan setiap type mesin sebagai berikut:

Tabel 1. Daftar Harga Bahan Baku

\begin{tabular}{|c|c|c|}
\hline \multirow{2}{*}{ Bahan Baku } & \multicolumn{2}{|c|}{ Harga } \\
\hline & Satuan (Ljr) & Satuan $(\mathrm{cm})$ \\
\hline UNP 8 & $\operatorname{Rp} 366.000$ & $\operatorname{Rp} 610$ \\
\hline UNP 6 & Rp 230.000 & $\operatorname{Rp} 383$ \\
\hline SIKU 5 & $\operatorname{Rp} 84.500$ & $\operatorname{Rp} 141$ \\
\hline Siku 4 & $\operatorname{Rp} 47.000$ & $\operatorname{Rp} 78$ \\
\hline AS 1 Setengah dim & Rp 655.000 & $\operatorname{Rp} 1.092$ \\
\hline Plat strip 2 setengah & $\operatorname{Rp} 42.000$ & $\operatorname{Rp} 70$ \\
\hline Pipa kotak 3,5 & $\operatorname{Rp} 96.000$ & Rp 161 \\
\hline Pipa kotak SS & $\operatorname{Rp} 121.000$ & Rp 202 \\
\hline Pipa kotak 5x5 & $\operatorname{Rp} 495.000$ & Rp 187 \\
\hline Beton neser 6mm & $\operatorname{Rp} 19.000$ & $\operatorname{Rp} 825$ \\
\hline AS 25 & Rp 295.000 & $\operatorname{Rp} 32$ \\
\hline AS 25 SS 304 & $\operatorname{Rp} 1.020 .800$ & Rp 492 \\
\hline AS 025 SS 201 & $\operatorname{Rp} 640.200$ & $\operatorname{Rp} 1.701$ \\
\hline
\end{tabular}


Vol. 01, No. 1, Mei, 2021

http://journal.um-surabaya.ac.id/index.php/sustainable/index

\begin{tabular}{|c|c|c|}
\hline \multirow{2}{*}{ Bahan Baku } & \multicolumn{2}{|c|}{ Harga } \\
\hline & Satuan (Ljr) & Satuan $(\mathrm{cm})$ \\
\hline$\overline{\text { AS } 016 \text { ST } 41}$ & $\operatorname{Rp} 123.000$ & Rp 1.067 \\
\hline AS 50,4 ST 41 & Rp 1.170.000 & Rp 205 \\
\hline $\begin{array}{l}\text { Pipa bulatt SS } 8 \mathrm{~mm} \mathrm{x} \\
0,3 \mathrm{~mm}\end{array}$ & Rp 656.000 & $\operatorname{Rp} 1.950$ \\
\hline Plat SS $2 \mathrm{~mm}$ & $\operatorname{Rp} 375.000$ & Rp 2.343 \\
\hline Plat hitam $1 \mathrm{~mm}$ & Rp 428.000 & Rp 1.578 \\
\hline Plat hitam 1,2 mm & $\operatorname{Rp} 478.000$ & Rp 2.283 \\
\hline Plat hitam 1,3mm & $\operatorname{Rp} 811.300$ & $\mathrm{Rp}-$ \\
\hline Plat hitam 1,4 mm & Rp 625.000 & $\operatorname{Rp} 2.731$ \\
\hline Plat SS 1,4 mm & Rp 428.000 & Rp 3.558 \\
\hline Plat SS 201 Imm & Rp 625.000 & Rp 2.741 \\
\hline
\end{tabular}

Sumber: PT.Cahaya Agro Teknik Surabaya,2021

Tabel 2. Biaya Bahan Baku Type Mesin Giling Plastik 50

\begin{tabular}{|c|c|c|c|c|c|}
\hline \multirow{2}{*}{ Bahan baku } & \multicolumn{5}{|c|}{ Harga } \\
\hline & Satuan (Ljr) & Satuan $(\mathrm{cm})$ & Uom & Kuantitas & Jumlah \\
\hline$\overline{\mathrm{UNP}} 8$ & $\operatorname{Rp} 276.500$ & $\operatorname{Rp} 461$ & $\mathrm{Cm}$ & 80 & $\operatorname{Rp} 36.880$ \\
\hline UNP 65 & Rp 230.000 & Rp 383 & $\mathrm{Cm}$ & 90 & $\mathrm{Rp} 34.470$ \\
\hline$\overline{\mathrm{UNP}} 5$ & Rp 152.000 & Rp 253 & $\mathrm{Cm}$ & 614 & Rp 155.342 \\
\hline Mur roda gila & & $\operatorname{Rp} 15.000$ & Pcs & 2 & $\operatorname{Rp} 30.000$ \\
\hline $\begin{array}{l}\text { Pisau giling/pisau } \\
\text { putar }\end{array}$ & & Rp 5.600 & $\mathrm{Cm}$ & 60 & Rp 336.000 \\
\hline $\begin{array}{l}\text { Pisau } \\
\text { Panjang/pisau } \\
\text { duduk }\end{array}$ & & Rp 5.600 & $\mathrm{Cm}$ & 80 & Rp 448.000 \\
\hline Roda gila 50/30 & & Rp 150.000 & Pcs & 1 & Rp 150.000 \\
\hline Baut $1 / 2$ & & Rp 1.500 & $\mathrm{Cm}$ & 12 & Rp 18.000 \\
\hline Plat strip 1" & Rp 112.200 & Rp 187 & Pcs & 140 & $\operatorname{Rp} 26.180$ \\
\hline AS 20 mm ST41 & Rp 188.000 & Rp 313 & Pcs & 40 & $\mathrm{Rp} 12.520$ \\
\hline $\begin{array}{l}\text { Pipa bulat } 26 \mathrm{~mm} x \\
3 \mathrm{~mm}\end{array}$ & Rp 12.500 & $\operatorname{Rp} 250$ & $\mathrm{Cm}$ & 40 & Rp 10.000 \\
\hline $\begin{array}{l}\text { Plat hitam } \\
1,5 \mathrm{~mm} 120 \times 240\end{array}$ & Rp 12.500 & $\operatorname{Rp} 20$ & $\mathrm{Cm}$ & 40 & Rp 248.920 \\
\hline $\begin{array}{l}\text { Plat hitam 1,5 mm } \\
120 \times 240\end{array}$ & Rp 587.000 & $\mathrm{Rp} 23$ & $\mathrm{Cm}$ & 12446 & Rp 3.312 \\
\hline $\begin{array}{l}\text { Plat hitam 8mm } \\
\text { 120x240 }\end{array}$ & Rp 659.00 & $\operatorname{Rp} 93$ & $\mathrm{Cm}$ & 144 & Rp 74.028 \\
\hline Slinder 50 & Rp 2.685.000 & Rp 12.500 & $\mathrm{Cm}$ & 796 & Rp 123.500 \\
\hline Pillow UCP 208 & & Rp 80.000 & $\mathrm{Cm}$ & 1 & Rp 123.500 \\
\hline & & Rp 320.000 & Pcs & 2 & Rp 160.000 \\
\hline Pully B4 30" & & & Pcs & 1 & Rp 320.000 \\
\hline TOTAL & & & & & Rp2.187.152 \\
\hline
\end{tabular}

Sumber: PT. Cahaya Agro Teknik Surabaya,2021 
Vol. 01, No. 1, Mei, 2021

http://journal.um-surabaya.ac.id/index.php/sustainable/index

Tabel 3. Biaya Bahan Baku Type Mesin Giling Plastik 100

\begin{tabular}{|c|c|c|c|c|c|}
\hline \multirow{2}{*}{ Bahan baku } & \multicolumn{5}{|c|}{ Harga } \\
\hline & Satuan (ljr) & Satuan $(\mathrm{Cm})$ & Uom & Kuantitas & Jumlah \\
\hline UNP 8 & $\operatorname{Rp} 276.500$ & $\operatorname{Rp} 461$ & $\mathrm{Cm}$ & 521 & $\operatorname{Rp} 240.181$ \\
\hline UNP 65 & $\operatorname{Rp} 230.000$ & $\operatorname{Rp} 383$ & $\mathrm{Cm}$ & 65 & Rp 24.895 \\
\hline Mur Roda gila & & Rp 15.000 & Pcs & 2 & $\operatorname{Rp} 30.000$ \\
\hline $\begin{array}{l}\text { Pisau giling/piasu } \\
\text { puter }\end{array}$ & & $\operatorname{Rp} 5.600$ & $\mathrm{Cm}$ & 90 & $\operatorname{Rp} 504.000$ \\
\hline $\begin{array}{l}\text { Pisau } \\
\text { Panjang/pisau } \\
\text { duduk }\end{array}$ & & $\operatorname{Rp} 5.600$ & $\mathrm{Cm}$ & 120 & Rp 672.000 \\
\hline Roda gila 50/30 & & Rp 150.000 & Pcs & 1 & Rp 150.000 \\
\hline Buat 5/8 & Rp 22.000 & $\operatorname{Rp} 3.142$ & Pcs & 12 & $\operatorname{Rp} 37.704$ \\
\hline Plat strip 2,5 & $\operatorname{Rp} 42.000$ & Rp 70 & $\mathrm{Cm}$ & 42 & Rp 2.940 \\
\hline Plat strip 1 & $\operatorname{Rp} 112.200$ & $\operatorname{Rp} 187$ & $\mathrm{Cm}$ & 90 & $\operatorname{Rp} 16.830$ \\
\hline AS 20mm ST41 & $\operatorname{Rp} 188.00$ & $\operatorname{Rp} 313$ & $\mathrm{Cm}$ & 16 & $\operatorname{Rp} 5.008$ \\
\hline $\begin{array}{l}\text { Serangan } 3 \\
(3 \mathrm{~mm}) 122\end{array}$ & $\operatorname{Rp} 1.230 .000$ & $\operatorname{Rp} 41$ & $\mathrm{Cm}$ & 105 & $\operatorname{Rp} 4.305$ \\
\hline Pillow UCF 210 & & Rp 105.400 & $\mathrm{Cm}$ & 2 & $\operatorname{Rp} 210.800$ \\
\hline Pillow B4 30 & & Rp 320.000 & PCS & 1 & Rp 320.000 \\
\hline & Total & & & & Rp 2.218.663 \\
\hline
\end{tabular}

Sumber: PT. Cahaya Agro Teknik Surabaya, 2021

Tabel 4. Biaya Bahan Baku Type Mesin Giling Plastik 200

\begin{tabular}{|c|c|c|c|c|c|}
\hline \multirow{2}{*}{ Bahan Baku } & \multicolumn{5}{|c|}{ Harga } \\
\hline & Satuan (Ljr) & Satuan $(\mathrm{Cm})$ & Uom & Kuantitas & Jumlah \\
\hline$\overline{\mathrm{UNP}} 8$ & Rp 276.000 & $\operatorname{Rp} 461$ & $\mathrm{Cm}$ & 45 & $\operatorname{Rp} 20.745$ \\
\hline UNP 65 & $\operatorname{Rp} 230.000$ & $\operatorname{Rp} 383$ & $\mathrm{Cm}$ & 264 & $\operatorname{Rp} 101.112$ \\
\hline UNP 10 & $\operatorname{Rp} 435.000$ & $\operatorname{Rp} 725$ & $\mathrm{Cm}$ & 180 & $\operatorname{Rp} 130.500$ \\
\hline Mur roda gila & & $\operatorname{Rp} 15.000$ & PCS & 2 & $\operatorname{Rp} 30.000$ \\
\hline $\begin{array}{l}\text { Pisau } \\
\text { giling/pisau putar }\end{array}$ & & $\operatorname{Rp} 5.600$ & $\mathrm{Cm}$ & 126 & $\operatorname{Rp} 705.600$ \\
\hline Pisau Panjang/pisau duduk & & Rp 5.600 & $\mathrm{Cm}$ & 152 & Rp 851.200 \\
\hline Roda gila 50/30 & & $\operatorname{Rp} 150.000$ & Pcs & 1 & $\operatorname{Rp} 150.000$ \\
\hline Baut 5/8 & $\operatorname{Rp} 22.000$ & $\operatorname{Rp} 3.142$ & Pcs & 4 & $\operatorname{Rp} 12.568$ \\
\hline$\overline{\text { Plat strip } 1}$ & $\operatorname{Rp} 112.200$ & $\operatorname{Rp} 187$ & $\mathrm{Cm}$ & 326 & $\operatorname{Rp} 60.962$ \\
\hline AS 20mm ST41 & Rp 188.000 & $\operatorname{Rp} 313$ & $\mathrm{Cm}$ & 32 & $\operatorname{Rp} 10.016$ \\
\hline Plat hitam $1.5 \mathrm{~mm} 120$ & $\operatorname{Rp} 587.000$ & $\operatorname{Rp} 20$ & Lbr & 25019 & Rp 500.380 \\
\hline $\begin{array}{l}\text { Serangan } \\
16(3 \mathrm{~mm})\end{array}$ & $\begin{array}{l}\mathrm{Rp} \\
1.050 .000\end{array}$ & $\operatorname{Rp} 35$ & Lbr & 170 & Rp 5.950 \\
\hline Pillow UCP 209 & & $\operatorname{Rp} 86.000$ & Pcs & 1 & $\operatorname{Rp} 86.000$ \\
\hline Pillow UCF 210 & & $\operatorname{Rp} 105.400$ & & 2 & $\operatorname{Rp} 210.800$ \\
\hline
\end{tabular}


Vol. 01, No. 1, Mei, 2021

http://journal.um-surabaya.ac.id/index.php/sustainable/index

\begin{tabular}{lllllc}
\hline \multirow{2}{*}{ Bahan Baku } & \multicolumn{5}{c}{ Harga } \\
\cline { 2 - 5 } & Satuan $(\mathrm{Ljr})$ & Satuan $(\mathrm{Cm})$ & Uom & Kuantitas & Jumlah \\
\hline TOTAL & & & & & Rp 2.875.833 \\
\hline
\end{tabular}

Sumber: PT. Cahaya Agro Teknik Surabaya,2021

Tabel 5. Bahan Baku Type Mesin Peras Santan

\begin{tabular}{|c|c|c|c|c|c|}
\hline \multirow{2}{*}{ Bahan baku } & \multicolumn{5}{|c|}{ Harga } \\
\hline & Satuan (Ljr) & Satuan $(\mathrm{Cm})$ & Uom & Kuantitas & Jumlah \\
\hline UNP 5 & Rp 152.000 & Rp 253 & $\mathrm{Cm}$ & 76 & Rp 19.228 \\
\hline$\overline{\text { SIKU } 5}$ & $\operatorname{Rp} 84.500$ & Rp 141 & $\mathrm{Cm}$ & 900 & Rp 126.900 \\
\hline Bearing UCFL 205 & & $\operatorname{Rp} 32.000$ & Pcs & 1 & $\operatorname{Rp} 32.000$ \\
\hline Bearing 620577 & & $\operatorname{Rp} 8.850$ & PCS & 2 & $\operatorname{Rp} 17.700$ \\
\hline $\begin{array}{l}\text { Snap ring } \\
\text { R52 }\end{array}$ & & $\operatorname{Rp} 3.000$ & Pcs & 1 & $\operatorname{Rp} 3.000$ \\
\hline$\overline{B a u t ~ 8 \times 25 m m}$ & Rp 540.000 & Rp 900 & PCS & 5 & $\operatorname{Rp} 1.600$ \\
\hline Baut 6x12 mm & Rp 1.080.000 & Rp 1.800 & Pcs & 8 & Rp 2.000 \\
\hline Baut 8x35mm & Rp 150.000 & Rp 250 & Pcs & 5 & $\operatorname{Rp} 2.000$ \\
\hline $\begin{array}{l}\text { Pipa bulat } \\
16 \mathrm{~mm} \times 11 \mathrm{~mm}\end{array}$ & Rp 120.000 & Rp 200 & Pcs & 7 & $\operatorname{Rp} 2.000$ \\
\hline $\begin{array}{l}\text { Pipa 50x5 } \\
\text {. }\end{array}$ & Rp 990.000 & Rp 1650 & Pcs & 80 & $\operatorname{Rp} 4.550$ \\
\hline Pipa 60 & Rp 77.500 & Rp 129 & $\mathrm{Cm}$ & 40 & Rp 72.000 \\
\hline Pipa strip 30 & Rp 52.000 & Rp 87 & $\mathrm{Cm}$ & 58 & Rp 72.000 \\
\hline$\overline{\text { Pipa 2,5 }}$ & Rp 725.000 & Rp 1.208 & PCS & 40 & Rp 14.500 \\
\hline$\overline{\text { Pipa kotak } 20}$ & Rp 220.500 & $\operatorname{Rp} 8$ & $\mathrm{Cm}$ & 30 & $\operatorname{Rp} 8.000$ \\
\hline Pipa kotak 10 & Rp 587.000 & Rp20 & Pcs & 200 & $\operatorname{Rp} 49.500$ \\
\hline AS 01 SS & Rp 3.058.000 & Rp 106 & $\mathrm{Cm}$ & 80 & $\operatorname{Rp} 25.800$ \\
\hline Plat hitam $0.6 \mathrm{~mm}$ & Rp 1.835.000 & $\operatorname{Rp} 64$ & Lbr & 54 & $\operatorname{Rp} 6.960$ \\
\hline Plat hitam 1,5 & Rp 255.000 & Rp 9 & Lbr & 576 & $\operatorname{Rp} 65.232$ \\
\hline $\begin{array}{l}\text { Plat SS 1,2 } \\
\text {. }\end{array}$ & Rp 760.000 & $\operatorname{Rp} 26$ & Lbr & 50 & Rp 4.608 \\
\hline Plat ss 6mm & Rp 4.000.000 & Rp 139 & Lbr & 877,5 & Rp 1000 \\
\hline Plat hitam $15 \mathrm{~mm}$ & Rp 5.200.000 & Rp 181 & Lbr & 334 & Rp 930.150 \\
\hline Roda 3 & & $\operatorname{Rp} 31.250$ & $\mathrm{Cm}$ & 10375 & $\operatorname{Rp} 21.374$ \\
\hline Mur baut $7 / 8$ & & $\operatorname{Rp} 2.500$ & $\mathrm{Cm}$ & 6606 & Rp 93.375 \\
\hline $\begin{array}{l}\text { Gearbox } 50 \\
\text { WPA ratio } 20\end{array}$ & & Rp 650.000 & Lbr & 392 & Rp 171.756 \\
\hline Sarangan 10 SS & Rp 1.300.000 & $\operatorname{Rp} 44$ & Pcs cm & 162 & Rp 54.488 \\
\hline Sarangan 0,5 & Rp 2.500.000 & Rp 125 & Lbr & 4 & Rp 29.322 \\
\hline Sarangan 5 & Rp 500.000 & $\operatorname{Rp} 17$ & & 1 & $\operatorname{Rp} 35.700$ \\
\hline TOTAL & & & & & Rp2.722.011 \\
\hline
\end{tabular}

Sumber: PT. Cahaya Agro Teknik Surabaya,2021

\section{b. Biaya Tenaga Kerja Langsung}

Biaya tenaga kerja yang dikeluarkan oleh Perusahaan PT. Cahaya Agro Teknik 


\section{Jurnal Sustainable}

Vol. 01, No. 1, Mei, 2021

http://journal.um-surabaya.ac.id/index.php/sustainable/index

Surabaya dalam memproduksi setiap type mesin yang terdiri dari mesin giling plastic 50, type mesin giling plsatik 100, type mesin giling plastic 200 dan mesin peras santan adalah sebagai berikut:

Tabel 6. Biaya Tenaga Kerja PT.Cahaya Agro Teknik

\begin{tabular}{|c|c|c|}
\hline $\begin{array}{l}\text { Karyawan } \\
\text { Produksi }\end{array}$ & Lama Pengerjaan & $\begin{array}{l}\text { Total Gaji } \\
\text { Karyawan }\end{array}$ \\
\hline $\begin{array}{l}\text { Mesin } \quad \text { Giling } 4 \text { Orang } \\
\text { Platik } 50\end{array}$ & Rp 56.485 & Rp 5.422.560 \\
\hline $\begin{array}{l}\text { Mesin giling } \quad 5 \text { Orang } \\
\text { plastic } 100\end{array}$ & $\operatorname{Rp} 56.485$ & $\begin{array}{l}\mathrm{Rp} \\
7.060 .625\end{array}$ \\
\hline $\begin{array}{ll}\text { Mesin } & \text { giling6 Orang } \\
\text { plastic } 200 & \end{array}$ & $\operatorname{Rp} 56.485$ & $\operatorname{Rp} 9.150 .750$ \\
\hline $\begin{array}{l}\text { Mesin peras } \\
\text { santan }\end{array}$ & Rp 56.485 & $\begin{array}{l}\mathrm{Rp} \\
3.389 .100\end{array}$ \\
\hline
\end{tabular}

Sumber: PT. Cahaya Agro Teknik Surabaya, 2021

c. Biaya Overhead Pabrik

Adapun biaya overhead pabrik tetap yang dikeluarkan oleh perusahaan PT.Cahaya Agro Teknik Surabaya adalah sebagai berikut:

1. Biaya Listrik Pabrik

Biaya listrik pabrik merupakan biaya yang dikeluarkan Setiap perusahaan selama proses produksi. Biaya listrik pabrik yang digunakan oleh perusahaan PT.Cahaya Agro Teknik Surabaya selama satu tahun (2020) adalah sebesar Rp 23.076.924, sedangkan untuk satu bulannya adalah sebesar Rp 1.923.077 untuk biaya yang dikeluarkan per harinya adalah sebesar Rp 19.230.

Tabel 7. Rincian Biaya Listrik Pabrik

\begin{tabular}{llllll}
\hline Type mesin & $\begin{array}{c}\text { Biaya listrik } \\
\text { per hari }\end{array}$ & $\begin{array}{c}\text { Lama } \\
\text { pengerjaan }\end{array}$ & $\begin{array}{c}\text { Produk yang } \\
\text { dihasilkan }\end{array}$ & $\begin{array}{c}\text { Biaya listrik } \\
\text { rata- rata }\end{array}$ & $\begin{array}{c}\text { Total listrik yang } \\
\text { dibutuhkan satu } \\
\text { bulan }\end{array}$ \\
\hline $\begin{array}{l}\text { Mesin giling } \\
\text { plastic 50 }\end{array}$ & Rp 19.230 & 24 Hari & 20 unit & Rp 23.076 & Rp 553.824 \\
$\begin{array}{l}\text { Mesin } \\
\text { giling plastic }\end{array}$ & Rp 19.230 & 25 Hari & 30 unit & Rp 16.025 & Rp 400.625 \\
100
\end{tabular}




\section{Jurnal Sustainable}

Vol. 01, No. 1, Mei, 2021

http://journal.um-surabaya.ac.id/index.php/sustainable/index

\begin{tabular}{llllll}
\hline \multicolumn{1}{|c}{ Type mesin } & $\begin{array}{c}\text { Biaya listrik } \\
\text { per hari }\end{array}$ & $\begin{array}{c}\text { Lama } \\
\text { pengerjaan }\end{array}$ & $\begin{array}{c}\text { Produk yang } \\
\text { dihasilkan }\end{array}$ & $\begin{array}{c}\text { Biaya listrik } \\
\text { rata- rata }\end{array}$ & $\begin{array}{c}\text { Total listrik yang } \\
\text { dibutuhkan satu } \\
\text { bulan }\end{array}$ \\
\hline $\begin{array}{l}\text { Mesin giling } \\
\text { plastic 200 }\end{array}$ & Rp 19.230 & 27 Hari & 40 unit & Rp 12.980 & Rp 350.466 \\
$\begin{array}{l}\text { Mesin peras } \\
\text { santan }\end{array}$ & Rp 19.230 & 20 Hari & 25 unit & Rp 15.384 & Rp 307.680 \\
\hline
\end{tabular}

Sumber: PT. Cahaya Agro Teknik Surabaya,2021

2. Biaya penyusutan alat produksi

Biaya penyusutan alat produksi adalah biaya akibat penggunaan dan waktu sehingga aktiva mengalami penilaian penurunan akibat pemakaian. Biaya penyusutan yang dikeluarkan oleh perusahaan PT. Cahaya Agro Teknik Surabaya adalah sebesar Rp 175.421.

Berikut adalah rincian biaya penyusutan alat produksi :

1. Biaya penyusutan mesin bubut 1 type c 62506

Biaya penyusutan per tahun : $\underline{\text { Harga Perolehan }}$

\section{Umur Ekonomis}

: $\underline{\operatorname{Rp} 85.000 .000}$

4 tahun

: Rp 21.250.000

Biaya penyusutan per bulan: biaya penyusutan pertahun, 12 bulan : $\underline{\operatorname{Rp} 21.250 .000}$

12 bulan

: Rp 1.770 .833

Biaya penyusutan per produksi: biaya penyusutan bulan, 30 hari : $\underline{\operatorname{Rp} 1.770 .833}$

30 hari

$$
\text { : Rp } 59.027
$$

2. Biaya penyusutan mesin bubut 2 type mesin c6232ai

Biaya penyusutan pertahun : Harga perolehan

Umur ekonomis

$: \operatorname{Rp} 38.500 .000$

4 tahun 


\section{Jurnal Sustainable}

Vol. 01, No. 1, Mei, 2021

http://journal.um-surabaya.ac.id/index.php/sustainable/index

$$
\text { : Rp } 9.625 .000
$$

Biaya penyusutan perbulan:biaya penyusutan tahun 12 bulan, $: \underline{\operatorname{Rp} 9.625 .000}$

12 bulan

: Rp 802.083

Biaya penyusutan produksi:biaya penyusutan bulan 30 hari, : $\underline{\operatorname{Rp} 802.083}$

30 hari

$$
\text { : Rp } 26.736
$$

3. Biaya penyusutan Gerinda Merk Bosch

Biaya penyusutan per tahun : Harga perolehan

$$
\begin{aligned}
& \text { Umur ekonomis } \\
& : \frac{\operatorname{Rp} 173.750}{4 \text { tahun }} \\
& : \operatorname{Rp} 43.437
\end{aligned}
$$

Biaya penyusutan perbulan : biaya penyusutan tahun 12 bulan, : $\underline{\operatorname{Rp} 43.437}$

12 bulan

$$
: \operatorname{Rp} 3.619
$$

Biaya penyusutan produksi : biaya penyusutan bulan 30 hari, : $\underline{\operatorname{Rp} 3.619}$

30 hari

$: \operatorname{Rp} 120,7$

4. Biaya penyusutan gerinda type Makita

Biaya penyusutan per tahun : Harga perolehan

Umur ekonomis

$$
\begin{aligned}
& : \frac{\operatorname{Rp} 660.000}{4 \text { tahun }} \\
& : \operatorname{Rp} 165.000
\end{aligned}
$$

Biaya penyusutan perbulan : biaya penyusutan tahun 12 bulan : $\underline{\operatorname{Rp} 165.000}$

12 bulan

$$
\text { : Rp } 13.750
$$

Biaya penyusutan produksi: biaya penyusutan bulan, 30 hari : $\underline{\operatorname{Rp} 13.750}$ 


\section{Jurnal Sustainable}

Vol. 01, No. 1, Mei, 2021

http://journal.um-surabaya.ac.id/index.php/sustainable/index
30 hari

: $\operatorname{Rp} 458,3$

5. Biaya penyusutan gerinda type Hitachi

Biaya penyusutan per tahun : Harga perolehan

Umur ekonomis

$: \underline{\operatorname{Rp} 171.500}$

4 tahun

: Rp 42.875

Biaya penyusutan per bulan: biaya penyusutan tahun 12 bulan, $\underline{\operatorname{Rp} 42.875}$

12 bulan

: Rp 3.572

Biaya penyusutan produksi: biaya penyusutan bulan 30 hari, : Rp 3.572

30 hari

: Rp 119.09

6. Biaya penyusutan mesin las merk antceh

Biaya penyusutan per tahun : $\underline{\text { Harga perolehan }}$

Umur ekonomis

$: \underline{7.000 .000}$

4 tahun

: Rp1.750.000

Biaya penyusutan per bulan: Biaya penyusutan tahun 12 bulan, $\underline{: R p 1.750 .000}$

12

: Rp 145.833

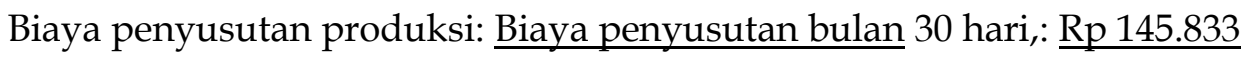

$30 \mathrm{~h}$ ari

: $\operatorname{Rp} 4.861$

7. Biaya penyusutan mesin las merk pegiono

Biaya penyusutan per tahun : Harga perolehan

Umur ekonomis 


\section{Jurnal Sustainable}

Vol. 01, No. 1, Mei, 2021

http://journal.um-surabaya.ac.id/index.php/sustainable/index

$$
\begin{aligned}
& : \frac{\operatorname{Rp} 12.127 .500}{4 \text { tahun }} \\
& : \text { Rp } 3.531 .875
\end{aligned}
$$

Biaya penyusutan bulan : biaya penyusutan tahun 12 bulan, : $\underline{\operatorname{Rp} 3.531 .875}$

Biaya penyusutan produksi : Biaya penyusutan bulan 30 hari, : $\underline{\operatorname{Rp} 294.322}$

$30 \mathrm{~h}$ ari

$$
\text { : Rp } 9.810
$$

8. Biaya penyustutan mesin las mig 60

Biaya penyusutan per tahun : $\underline{\text { Harga perolehan }}$

$$
\text { Umur ekonomis }
$$$$
\text { : } \underline{\operatorname{Rp} 4.140 .000}
$$$$
4 \text { tahun }
$$$$
\text { : Rp } 1.028 .500
$$

Biaya penyusutan bulan : Biaya penyusutan per tahun 12 bulan,: $\underline{\operatorname{Rp} 1.028 .500}$

12 bulan

$$
\text { : Rp } 85.708
$$

Biaya penyusutan produksi: Biaya penyusutan bulan 30 hari, : $\underline{\operatorname{Rp} 85.708}$

$30 \mathrm{~h}$ ari

: Rp 2.856

9. Biaya penyusutan mesin las merk techlend

Biaya penyusutan tahun: Harga perolehan

$$
\begin{aligned}
& \text { Umur ekonomis } \\
& : \frac{\operatorname{Rp} 3.800 .000}{4 \text { tahun }} \\
& : \operatorname{Rp} 950.000
\end{aligned}
$$

Biaya penyusutan bulan: Biaya penyusutan tahun 12 bulan, : $\underline{\operatorname{Rp} 950.000}$ 


\section{Jurnal Sustainable}

Vol. 01, No. 1, Mei, 2021

http://journal.um-surabaya.ac.id/index.php/sustainable/index

12 bulan

: $\operatorname{Rp} 79.166$

Biaya penyusutan produksi: Biaya penyusutan bulan 30 hari,: $\underline{\operatorname{Rp} 79.166}$

30 hari

: $\operatorname{Rp} 2.638$

3. Biaya reparasi dan pemeliharaan pabrik

Biaya reparasi dan pemeliharaan pabrik merupakan biaya overhead pabrik dan harga jasa yang perlu dikeluarkan sebuah perusaahan untuk keperluan perbaikan dan pemeliharaan mesin produksi. Kendaraan dan alat-alat perusahaan lainnya. Biaya reparasi dan pemeliharaan yang dikeluarkan oleh perusahaan PT.Cahaya Agro Surabaya adalah sebesar Rp 177.208 dalam satu kali produksi.

Tabel 8. Rincian Biaya Listrik Pabrik

\begin{tabular}{llllll}
\hline \multicolumn{1}{|c}{ Type mesin } & $\begin{array}{c}\text { Biaya listrik } \\
\text { per hari }\end{array}$ & $\begin{array}{c}\text { Lama } \\
\text { pengerjaan }\end{array}$ & $\begin{array}{c}\text { Produk yang } \\
\text { dihasilkan }\end{array}$ & $\begin{array}{c}\text { Biaya listrik } \\
\text { rata- rata }\end{array}$ & $\begin{array}{c}\text { Total listrik yang } \\
\text { dibutuhkan satu } \\
\text { bulan }\end{array}$ \\
\hline $\begin{array}{l}\text { Mesin giling } \\
\text { plastic 50 }\end{array}$ & Rp 19.230 & 24 Hari & 20 unit & Rp 23.076 & Rp 553.824 \\
$\begin{array}{l}\text { Mesin } \\
\text { giling plastic }\end{array}$ & Rp 19.230 & 25 Hari & 30 unit & Rp 16.025 & Rp 400.625 \\
$\begin{array}{l}\text { 100 } \\
\begin{array}{l}\text { Mesin giling } \\
\text { plastic 200 }\end{array}\end{array}$ & Rp 19.230 & 27 Hari & 40 unit & Rp 12.980 & Rp 350.466 \\
$\begin{array}{l}\text { Mesin peras } \\
\text { santan }\end{array}$ & Rp 19.230 & 20 Hari & 25 unit & Rp 15.384 & Rp 307.680 \\
\hline
\end{tabular}

Sumber: PT. Cahaya Agro Teknik Surabaya,2021

\section{Biaya Produksi}

Biaya produksi adalah biaya yang timbul akibat adanya fungsi produksi. Berikut adalah bahan baku yang dibutuhkan memproduksi setiap type mesin yang terdiri dari sebagai berikut: 


\section{Jurnal Sustainable}

Vol. 01, No. 1, Mei, 2021

http://journal.um-surabaya.ac.id/index.php/sustainable/index

Tabel 9. Daftar Rincian Type Mesin

\begin{tabular}{|c|c|}
\hline Type Mesin & Bahan Baku yang dibutuhkan \\
\hline Type mesin giling plastic 50 & $\begin{array}{l}\text { Unp } 8 \text {, unp } 65 \text {, unp } 5 \text {, mur roda gila, pisau } \\
\text { giling/ pisau putar, pisau Panjang/ pisau duduk, } \\
\text { roda gila } 50 / 30 \text {, baut } 1 / 2 \text {, plat strip } 1 \text {, AS } 20 \mathrm{~mm} \\
\text { ST41, Pipa bulat } 26 \mathrm{~mm} \times 3 \mathrm{~mm} \text {, plat hitam } 1,2 \mathrm{~mm} \\
120 \times 240 \text {, plat hitam } 2 \mathrm{~mm} \times 240 \text {, plat hitam } 2 \mathrm{~mm} \mathrm{x} \\
8 \mathrm{~mm} 120 \times 240 \text {, slinder } 50 \text {, pillow UCP } \\
208 \text {, Pillow b4 } 30 \text {. }\end{array}$ \\
\hline \multirow[t]{2}{*}{ Type mesin giling plastic 100} & $\begin{array}{l}\text { UNP 8, UNP 65, Mur roda gila, pisau } \\
\text { giling/pisau putar, pisau Panjang/pisau duduk, } \\
\text { roda gila } 300 / 500 \text {, baut } 5 / 8 \text {, plat strip } 2,5 \text {, plat } \\
\text { strip 1, AS }\end{array}$ \\
\hline & $\begin{array}{l}\text { 20mm ST 41, Serangan (3mm) 122x 244, pillow } \\
\text { UCF 210, Pully B4 } 30 .\end{array}$ \\
\hline Type Mesin giling plastic 200 & $\begin{array}{l}\text { UNP 8, UNP 65, UNP 10, Mur } \\
\text { roda gila, pisau giling/pisau putar, pisau } \\
\text { Panjang/pisau duduk, roda gila 50/30, baut } 5 / 8, \\
\text { plat strip1, AS 20mm ST41, Plat hitam } 1,5 \mathrm{~mm} 120 \\
\text { x 240, sarangan } 16(3 \mathrm{~mm}) 122 \times 244 \text {, pillow ucp } \\
213 \text {, }\end{array}$ \\
\hline Type Mesin peras santan & $\begin{array}{l}\text { UBP } 6 \text {, Suku } 5 \text {, Bearing UCFL } 620577 \text {, snap ring } \\
\text { R52, baut } 8 \times 25 \mathrm{~mm} \text {, baut } 6 \times 12 \mathrm{~mm} \text {, pipa bulat } \\
16 \mathrm{~mm} \times 11 \mathrm{~mm} \text {, pipa } 50 \times 5 \mathrm{~mm} \text {, pipa } 60 \times 6 \mathrm{~mm} \text {, pipa } \\
\text { strip } 40 \times 3 \mathrm{~mm} \text {, pipa strip } 30 \times 6 \mathrm{~mm} \text {,pipa } 50 \times 5 \mathrm{~mm} \text {, } \\
\text { pipa kotak } 20 \times 10 \text { tbl } 1 \mathrm{~mm} \text { ss } 201 \text {, plat hitam } \\
0,6 \mathrm{~mm} \times 120 \times 60 \text {, plat hitam } 1,5 \mathrm{~mm} 12 \times 240 \text {, } \\
\text { plat ss } 5 \mathrm{~mm} 201122 \times 240 \text {, plat ss } 5 \mathrm{~mm} 201 \\
122 \times 244 \text {, plat ss } 0,6201122 \times 244 \text {, plat ss } \\
1,2201122 \times 244 \text {, plat ss } \\
6 \mathrm{~mm} 201122 \times 224 \text {, plat } \\
\text { hitam } 15 \mathrm{~mm} 120 \times 240 \text {, roda } 3 \text {, mur baut, gear } \\
\text { box } 50 \text { wpa ratio } 20 \text {, serangan } 10 \mathrm{ss}(0,5) 100 \times 200,\end{array}$ \\
\hline & serangan $5(1,2 \mathrm{~mm}) 122 \times 240$ \\
\hline
\end{tabular}

Tabel 10. Biaya Produksi Setiap Type Mesin

\begin{tabular}{|c|c|c|c|c|}
\hline \multirow{3}{*}{ Keterangan } & \multicolumn{4}{|c|}{ Total biaya produksi } \\
\hline & Mesin giling & Mesin & Mesin & Mesin \\
\hline & plastic 50 & plastic 100 & plastic 200 & santan \\
\hline Biaya bahan baku & Rp2.187.152 & $\operatorname{Rp} 2.218 .663$ & Rp2.875.883 & Rp2.722.011 \\
\hline $\begin{array}{l}\text { Biaya tenaga kerja } \\
\text { langsung }\end{array}$ & Rp5.442.560 & $\operatorname{Rp} 7.060 .625$ & Rp9.150.570 & Rp3.389.100 \\
\hline Biaya overhead pabrik & $\operatorname{Rp} 906.240$ & $\operatorname{Rp} 753.254$ & Rp703.095 & Rp600.306 \\
\hline
\end{tabular}


Vol. 01, No. 1, Mei, 2021

http://journal.um-surabaya.ac.id/index.php/sustainable/index

\begin{tabular}{lccccc}
\hline & \multicolumn{5}{c}{ Total biaya produksi } \\
\cline { 2 - 6 } Keterangan & $\begin{array}{c}\text { Mesin giling } \\
\text { plastic 50 }\end{array}$ & $\begin{array}{c}\text { Mesin } \\
\text { plastic 100 }\end{array}$ & $\begin{array}{c}\text { Mesin piling } \\
\text { plastic 200 }\end{array}$ & $\begin{array}{c}\text { Mesin peras } \\
\text { santan }\end{array}$ \\
\hline Total biaya produksi & Rp 8.536.165 & Rp10.032.542 & Rp12.729.758 & Rp6.771.417 \\
\hline
\end{tabular}

Sumber: PT. Cahaya Agro Teknik Surabaya, 2021

3. Perhitungan menggunakan Metode full costing perhitungan menurut perusahaan PT.Cahaya Agro Teknik Surabaya

Dapat dianalisis bahwa total biaya yang dikeluarkan untuk memproduksi setiap unit mesin memiliki harga pokok produksi yang berbeda-beda untuk memproduksi mesin giling plastic 50 adalah sebesar Rp 170.723.300, mesin giling plastic 100 sebesar Rp 300.976.260, mesin giling plastic 200 sebesar Rp 509.412.520, dan mesin peras santan sebesar Rp 169.424.300

4. Perhitungan Harga Pokok Produksi Menurut PT.Cahaya Agro Teknik Perhitungan harga pokok produksi menurut PT.Cahaya Agro Teknik

Analisis bahwa perhitungan harga pokok produksi menurut perusahaan PT. Cahaya Agro Teknik untuk type mesin giling plastic 50 sebesar Rp 167.179.080 type mesin giling plastic 100 sebesar Rp292.960.020 type mesin giling plastic 200 sebesar Rp502.093.600 dan type mesin peras santan sebesar Rp161.548.825 dengan menganalisis apabila PT. Cahaya Agro Teknik dalam perhitungan harga pokok produksi menggunakan metode full costing adalah menghitung seluruh biaya yang dikeluarkan proses produksi, dari perhitungan harga pokok produksi yang telah di analisis menggunakan metode fuul costing sudah mengklasifikasikan semua biaya produksi baik yang bersifat variable maupun tetap. Dalam perhitungan harga pokok produksi menurut perusahaan sudah bisa dikatakan baik tetapi dalam pengklasifikasi biaya belum semua di klasifikasikan seperti biaya pemeliharan pabrik.

\section{Hasil Analisis}

Perbandingan perhitungan harga pokok produksi menggunakan metode full costing dan menurut perusahaan PT. Cahaya Agro Teknik adalah sebagai berikut : 
Vol. 01, No. 1, Mei, 2021

http://journal.um-surabaya.ac.id/index.php/sustainable/index

Tabel 11. Hasil Perbandingan

\begin{tabular}{|c|c|c|c|c|}
\hline Keterangan & Type mesin & Metode full costing & $\begin{array}{c}\text { Metode PT.Cahaya Agro } \\
\text { Teknik }\end{array}$ & Selisih \\
\hline \multirow[t]{4}{*}{ Biaya produksi } & Mesin giling plastic 50 & Rp8.541.720 & Rp8.358.957 & $\operatorname{Rp} 182.763$ \\
\hline & Mesin giling plastic 100 & Rp10.038.097 & Rp9.765.334 & $\operatorname{Rp} 272.7663$ \\
\hline & Mesin giling plastic 200 & Rp12.735.313 & Rp12.552.340 & $\operatorname{Rp} 182.973$ \\
\hline & Mesin peras santan & Rp6.776.972 & Rp6.461.953 & $\operatorname{Rp} 315.019$ \\
\hline \multirow{4}{*}{$\begin{array}{l}\text { Jumlah yang } \\
\text { diproduksi }\end{array}$} & Mesin giling plastic 50 & 20 & 20 & - \\
\hline & Mesin giling plastic 100 & 30 & 30 & - \\
\hline & Mesin giling plastic 200 & 40 & 40 & - \\
\hline & Mesin peras santan & 25 & 25 & - \\
\hline
\end{tabular}

\section{KESIMPULAN}

1. PT. Cahaya Agro Teknik belum tepat dalam melakukan pengklasifikasian dan penggolongan biaya ke dalam komponen biaya produksi, dan penggolongan pembebanan biaya yang kurang tepat. Biaya yang seharusnya dikelompokkan kedalam biaya produksi tetapi perusahaan memasukkan ke dalam biaya nonproduksi. Dalam perhitungan harga pokok produksi yang telah dianalisis metode full costing pada PT. Cahaya Agro Teknik adalah menghitung seluruh biaya yang dikeluarkan dalam proses produksi type mesin giling plastic $50 \mathrm{Rp}$ 170.723.300, type mesin giling plastic $100 \mathrm{Rp}$ 300.976.260, type giling plastic $200 \mathrm{Rp} 509.424 .300$, dan type mesin peras santan sebesar Rp 169.424.300.

2. Perhitungan dengan metode full costing dalam perhitungan menghasilkan nilai yang tinggi dibandingkan dengan perhitungan menurut perusahaan, hal ini dikarenakan metode full costing memperhitungkan seluruh biaya selama kegiatan produksi baik yang bersifat variable maupun biaya tetap.

3. Perhitungan harga pokok produksi metode full costing lebih besar dibandingkan dengan perhitungan harga pokok produksi menurut perusahaan.

\section{SARAN}

Setelah penulis menganalisis antara perhitungan harga pokok produksi yang dihitung oleh perusahaan dan perhitungan menggunakan metode full costing sebaiknya PT. Cahaya Agro 


\section{Jurnal Sustainable}

Vol. 01, No. 1, Mei, 2021

http://journal.um-surabaya.ac.id/index.php/sustainable/index

Teknik maka perhitungan biaya produksinya lebih akurat dan terperinci dibandingkan dengan metode perhitungan menurut perusahaan. Dan dengan metode full costing nantinya akan membantu perusahaan dalam pengambilan keputusan khususnya anggaran.

\section{DAFTAR PUSTAKA}

A.Hernita. (2020). Analisis Varians Terhadap Biaya Produksi Batu Bata di CV.Tujuh Wali Desa Massangkae Kecamatan Kejuara Kabupaten Bone. Fakultas Ekonomi Dan Hukum Islam Institut Agama Islam (IAI) Muhammadiyah Sinjai.

Asprilia, N. (2019). Analisis Penerapan PerhitunganHarga Pokok Menggunakan Metode Full Costing Dalam Pencapain Laba Pada PT.Smber Rejeki Varia Di Surabaya .Fakultas Ekonomi Universitas Bhayangkara Surabaya.

Rusdiyanto. (2016). Analisis Biaya Produksi Pada PabriSelang Air Di PT.Maspion IV Surabaya .Fakultas Ekonomi, Universitas Gresik.

Sudarma, A. (2016). Analisis Penentuan Harga PokokProduksi Dengan Metode Full Costing Sebagai Dasar Penetapan Harga Jual Pada CV.Salwa Maubel2. Universitas Muhammadiyah Sukabumi.

Suwardjono. (2013). Akuntansi Pengantar. Dosen Fakultas Ekonomika dan Bisnis Universitas Gadjah Mada: 6.

Suwardjono. (2013). Akuntansi Pengantar. Dosen Fakultas Ekonomika dan Bisnis Universitas Gadjah Mada: 5.

Suwaryo Gito Saputro, N. d. (2020). Analisis Biaya Produksi Furnitur: Studi Kasus di Mebel Barokah 3, Marga Agung Village, Lampung Selatan. Fakultas Pertanian Universitas Lampung. 


\section{Jurnal Sustainable}

Vol. 01, No. 1, Mei, 2021

http://journal.um-surabaya.ac.id/index.php/sustainable/index 